Vol. 15, No. 1, 2012, 1-11

http://dx.doi.org/10.5229/JKES.2012.15.1.001

리튬 이차전지용 고체전해질 개발 동향

\author{
서순성 ${ }^{\dagger \dagger}$ - 이철우 ${ }^{\dagger, *}$ - 김 건 ${ }^{\dagger, *}$ \\ 고려대학교 화학과, "삼성 SDI, "†성신여자대학교 화학과
}

(2011년 11월 17일 접수 : 2011년 12월 4일 채택)

\title{
Research Trend of Solid Electrolyte for Lithium Rechargeable Batteries
}

\author{
Soon-Sung Suh ${ }^{\dagger, \dagger}$, Cheol-Woo $\mathrm{Yi}^{\dagger+{ }^{\dagger+}, *}$, and Keon $\mathrm{Kim}^{\dagger, *}$ \\ tDepartment of Chemistry, Korea University, Seoul 136-701, South Korea \\ ${ }^{\dagger}$ Energy lab, Corporate R\&D Center, Samsung SDI Co. Ltd., Yongin-City, Korea \\ ${ }^{t h t}$ Department of Chemistry and Institute of Basic Science, Sungshin Women's University, Seoul 143-732, South Korea
}

(Received November 17, 2011 Accepted December 4, 2011)

\begin{abstract}
초 록
최근 리튬이차전지는 높은 에너지 밀도와 고용량화되어 급속도로 발전하고 있다. 그 중에서도 친 환경 수송 장치의 전기자동차가 주목 받고 있는데 이를 위해서는 리튬이차전지의 많은 성능개선이 요구된다. 현재 리튬이차전지는 '하이브리드 전기자동차 (Hybrid Electric Vehicle, HEV)'에 실제 적용되고 있으며 이를 위해서 높은 용량, 긴 수명, 그리고 안전성 확보가 반드시 필요하다. 하지만 현재 리튬이차전지에서 리튬이온의 이동을 위해 사용하는 유기전해액의 과열 및 과충전 상태에서 폭발의 위험성을 가지고 있기에 높은 안전성을 가진 고체전해질로의 대체가 시급하다. 따라서 본 연구에서는 리튬이차전지의 안정성 및 성능 개선을 위한 고체전해질의 연구 동향과 출원된 특허 및 논문에 대하여 논의하고자 한다.
\end{abstract}

\begin{abstract}
Recently lithium ion secondary batteries (LIB) have rapidly developed because of their advantages such as high energy densities and capacities. Among them, an electrical vehicle which is the one of the environmental-friendly transportation facilities has been received a great attention, but, it is needed to overcome several obstacles of the LIB performances. LIB is practically adapted to Hybrid Electric Vehicle (HEV), but the issues for high capacities, long life time and safety should be solved. Moreover, LIBs still have some possibilities of explosion in the case of overheating of the used organic electrolyte and overcharging of the cell. Hence, it is urgently needed to replace the liquid electrolytes into the solid electrolytes due to the safety issues. Therefore, in this review, we summarized and discussed the research trends of the solid electrolyte to solve the concerns of safety and capacity of LIBs and published patents and articles.
\end{abstract}

Keywords: Solid electrolyte, Li-ion battery, All-solid battery, Safety, LISICON, NASICON

*E-mail: cheolwoo@sungshin.ac.kr, kkim@korea.ac.kr 


\section{1. 서 론}

리튬이차전지의 기술은 최근 현저한 발전을 통하여 현재 다양한 분야에서 응용되고 있으나, 전지의 용량, 안전성, 출력, 대형화, 초소형화 등의 관점에서 현재 리튬이차전지의 한계를 극복할 수 있는 다양한 전지 들이 연구되고 있다. 대표적으로 현재의 리튬이차전지에 비해 용량 측면에서 이론 용량이 매우 큰 금속-공기 전지 (metal-air battery), 안전성 측면에서 폭발 위험이 없는 전고체전지 (all solid battery), 출력 측면에서 리튬이차전지에 비해 출력 특성이 우수한 슈퍼 캐퍼시터 (supercapacitor), 대형화 측면에서는 $\mathrm{NaS}$ 전지 혹은 RFB (redox flow battery), 초소형화 측면에서는 박막전지 (thin film battery) 등이 학계 및 산업계에서 지속적인 연구가 진행되고 있다. ${ }^{1-7)}$

본 논문에서는 안전성 측면에서 궁극적인 기술 개발 목표인 전고체전지, 특히 전고체전지의 핵심 기술인 고 체전해질의 기술의 개발 동향에 대하여 알아보고자 한 다. Fig. 1에 전고체전지의 개략도를 나타내었다. Fig. 1 에서 보인 바와 같이 전고체전지는 기존에 리튬이차전지 에서 사용되는 액체전해질을 고체로 대체하며 전해액의 분해반응 등에 의한 발화, 폭발이 전혀 발생하지 않으 므로 안전성을 대폭 개선할 수 있다. 또한, 음극 소재로 Li-metal 혹은 Li-alloy 를 사용할 수 있기 때문에 전지의 질량 및 부피에 대한 에너지 밀도를 획기적으로 향상시 킬 수 있는 장점이 있다. ${ }^{8-9)}$ 이에 반하여, 고체 전해질을 사용할 경우 고체전해질의 이온전도성이 낮고, 액체 전 해질 사용시보다 전극/전해질 계면 상태가 좋지 않기 때 문에 전지의 성능이 저하되는 단점이 있다. ${ }^{10)}$ 현재 여러 가지 고체전해질이 연구되고 있는데, 본 연구에서는 산화 물계와 황화물계 무기 고체전해질의 연구동향과 출원된 특허 및 논문을 분석하여 고체전해질을 통한 현재의 LIB 성능개선 방법에 대한 고찰이 이루어 졌다.

\section{2. 본 론}

\section{1. 리튬이온 전도도}

고체 내부에서 고속으로 리튬이온을 확산시킬 수 있는 물질을 고체전해질이라 하고, 고체전해질 중에 이온전 도율이 높고 $\left(10^{-3} \mathrm{~S} / \mathrm{cm}\right)$, 전기화학적 안정성이 우수한 물질에 대한 연구가 진행되고 있다. ${ }^{11)}$ 이러한 고체전 해질의 연구는 결정질, 글래스 (비정질), 폴리머, 복합물 (composite) 등의 다양한 형상의 물질에 대해 진행되고 있으며, ${ }^{12)}$ 이러한 고체전해질을 이용한 전고체전지의 개 발도 함께 진행되고 있다. 특히 글래스계에는 산황화물인 $\mathrm{Li}_{3} \mathrm{PO}_{4}-\mathrm{Li}_{2} \mathrm{~S}-\mathrm{SiS}_{2}$ 가 높은 이온전도도 $\left(10^{-3} \mathrm{~S} / \mathrm{cm}\right)$ 와 안 정된 전기화학반응을 하는 것으로 알려져 있고, ${ }^{13)}$ 황화

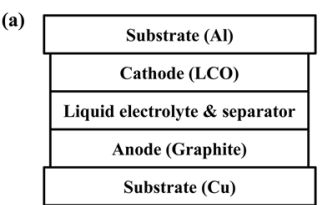

(b)

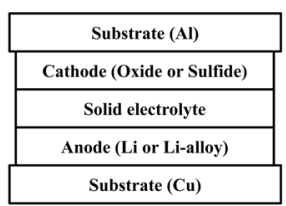

Fig. 1. Schematic diagram of Conventional LIB (a) and All Solid Battery (b).

물-할로겐화합물 $\left(\mathrm{LiI}-\mathrm{Li}_{2} \mathrm{~S}-\mathrm{P}_{2} \mathrm{~S}_{5}\right)$ 의 경우도 $10^{-4} \mathrm{~S} / \mathrm{cm}$ 의 비교적 높은 이온전도도를 보여주고 있다. ${ }^{14)}$ 일반적으로 많은 리튬이온 전도체 중 글래스계 물질이 결정성 물질 보다 높은 전도도를 보이고 있다.

무기세라믹복합물의 이온전달 메커니즘은 결함에 의한 ionic point defect 와 정전기적 인력 및 척력이 주요 인자이다. 결함에 의한 이론은 Schottky 결함 (Fig. 2(a))와 Frenkel 결함 (Fig. 2(b))으로 설명할 수 있다. Schottky 결함은 빈 자리가 양이온/음이온 쌍으로 형성되고 Frenkel 결합은 다른 위치의 틈새 원자의 쌍으로 결함이 만들어 지게 된다. 고체 구조는 결함 형태에 영향을 미쳐 Frenkel 결함은 배위수가 작고 공유결합 성질이 더 강한 고체에 서 형성되고 Schottky 결함은 이온결합 성질이 더 큰 물질에서 나타난다. ${ }^{15)}$ Fig. 3은 글래스 전해질에서 정전 (a)

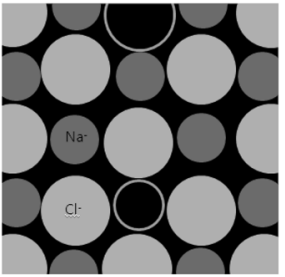

(b)

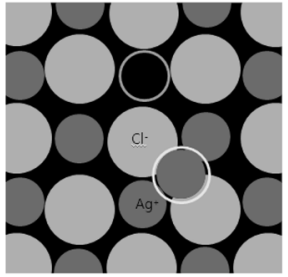

Fig. 2. Comparison of ion point defects: (a) Schottky dificiency, (b) Frenkel deficiency.

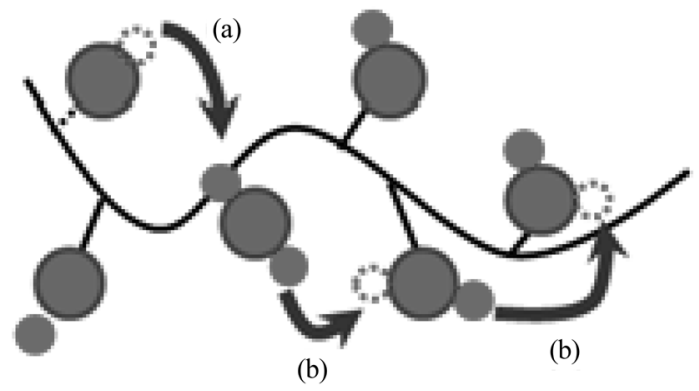

Fig. 3. Ion transfer mechanism of the glass electrolyte: (a) Interstitial cationic formation and (b) Migration from one NBO to another. 
기적 인력 및 척력에 의한 이온전달 메커니즘을 보여주 는데 이온전도성을 증가시키기 위해서는 charge carrier concentration $\left(\mathrm{C}_{\mathrm{Li}}\right)$ 를 증가시키고 이온전도를 위한 활성 화 에너지의 감소가 필요한 것을 알 수 있다. Fig. 4에서 보인 바와 같이 활성화 에너지는 $\mathrm{E}_{\text {strain }}+\mathrm{E}_{\text {electrostatic }}$ 으로 정의할 수 있고 이온이 글래스의 non-bridging oxygen (NBO) 사이를 이동할 때 bridging oxygen $(\mathrm{BO})$ 에 의해 생성된 틈새의 크기에 의해 결정되는 strain energy와 양이온과 음이온으로 구성된 glass network을 통과할 때 발생하는 정전기적 인력 및 척력인 electrostatic energy에 의해 결정된다. ${ }^{16)}$

따라서, 고체전해질에서 높은 이온 전도도는 이동 메커 니즘과 이동에 필요한 활성화 에너지로 설명할 수 있다. 상온에서 확산속도가 빠른 물질은 다음과 같은 특징이 있는데, 이는 낮은 활성화 에너지, 적은 전하수와 작은 반지름, 내성 또는 외성 결함들의 높은 농도 등의 조건이 필요하게 된다. ${ }^{17)}$

\section{2. 무기물계 고체전해질}

앞서 언급한 바와 같이 무기물계 고체 전해질은 황화 물계와 산화물계로 구분할 수 있다. 현재 가장 많은 기술 개발이 진행된 고체전해질은 황화물계 고체전해질이며, 이 고체전해질의 이온전도도는 $10^{-2} \mathrm{~S} / \mathrm{cm}^{18)}$ 로 유기 전해 액에 근접한 수준의 이온 전도도를 가진 재료까지 개발 이 되었다. 그러나, 황화물계 고체전해질은 유기 전해액 대비 전극 활물질과 고체 전해질의 계면저항이 높고, 물 과 반응해 황화수소 $\left(\mathrm{H}_{2} \mathrm{~S}\right)$ 가 발생하기 때문에 습도의 제어가 반드시 필요하다. 또한, 산화물계 고체전해질로는 결정성과 비정질 고체전해질이 있으며, 결정성 고체전해 질은 격자 결함으로 리튬이온이 이동할 수 있는 통로가 형성되어 높은 이온 전도성을 가지고 있다. 대표적인 산 화물계 고체전해질로 Li-La-Ti-O가 있다. 그러나, 이러한 고체전해질은 결정성에 의한 grain boundary의 입계저항
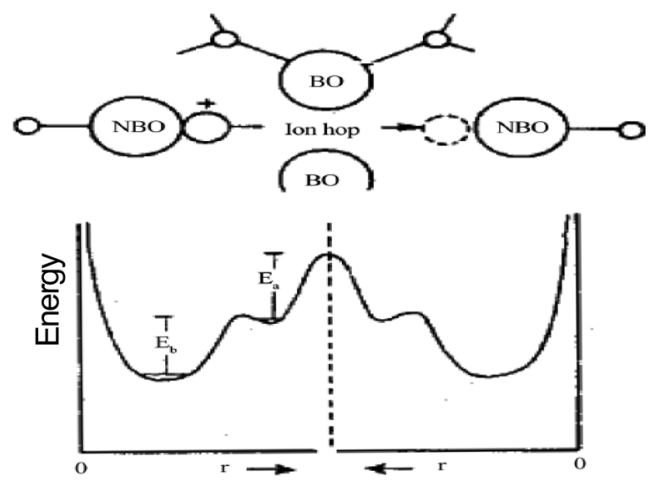

Fig. 4. Ion transfer and the activation energy.
때문에 이온 전도도가 감소하는 단점이 있다. ${ }^{19}$ 또한 결 정화를 위해 고온의 열처리가 필요하기 때문에 조성 선 택의 제한 및 전극/전해질 계면 특성이 저하되고, 전이금 속의 환원에 의해 전자 전도도의 감소가 발생하는 단점이 있어서 비교적 낮은 이온전도도 $\left(10^{-3}-10^{-5} \mathrm{~S} / \mathrm{cm}\right)$ 를 가 진다. ${ }^{20)}$ 따라서 현재 비정질 산화물 고체전해질에 대한 많은 연구가 진행되고 있는데, 비정질 고체전해질은 리 튬이온이 이동 할 수 있는 넓은 공간을 가지고 있기 때 문에 높은 이온전도성을 가지는 특성이 있다. ${ }^{21)}$ 산화물계 중 인산염 화합물계열 $\left(\mathrm{LiTi}\left(\mathrm{PO}_{4}\right)_{3}\right)$ 은 높은 이온전도도를 보이고, 다른 산화물계 고체전해질과는 다르게 결정화 유 리 상태로 제작이 가능하다. 이와 같이 결정화 유리상태 로 제작된 인산염 화합물 계열의 고체전해질은 입자와 입자 사이가 유리질로 존재하여 입자 사이의 저항을 감소시킬 수 있기 때문에 높은 이온전도도를 가질 수 있다. ${ }^{22)}$

이러한 장단점이 있는 무기물계 고체전해질들을 전 고체 전지에 응용하여 높은 성능을 구현하기 위해서는 전극재료 자체의 우수한 물성 및 전극재료와 고체전해질 사이에 양호한 계면을 형성하는 것이 중요하다. 단순히 고체전해질과 전극재료를 적층하는 것은 고체전해질과 전극재료와의 접점 (point contact)이 형성되어 계면저항을 증가시키기 때문에 전지에 응용이 불가능하다. 따라서, 최근에는 전극재료와 고체전해질은 혼합한 전극복합재 료를 이용하는 연구가 진행되고 있다.

\subsubsection{NASICON-type $\mathrm{Li}$ ion conductors}

NASICON은 (Na super-ionic conductor)의 약자로 $\beta$-alumina, $\mathrm{Na}_{3} \mathrm{Zr}_{2} \mathrm{Si}_{2} \mathrm{PO}_{12}, \mathrm{NaZr}_{2}\left(\mathrm{PO}_{4}\right)_{3}$ 의 구조를 말하 는데 $\mathrm{NaZr}_{2}\left(\mathrm{PO}_{4}\right)_{3}$ 의 경우 $300^{\circ} \mathrm{C}$ 에서 $10^{-5} \mathrm{~S} / \mathrm{cm}$ 정도의 낮은 이온전도도를 보이지만 $\mathrm{Na}$ 을 $\mathrm{Li}$ 으로 치환시킨 경우 전도도가 10 배 정도 증가된다고 보고되어 있으며,23) 현재 $\mathrm{Na}$ 과 $\mathrm{Zn}$ 를 $\mathrm{Li}$ 과 $\mathrm{Ti}$ 이온으로 치환하고 일부 $\mathrm{Al}$ 을 포함하는 $\mathrm{Li}_{1+\mathrm{x}} \mathrm{Ti}_{2-\mathrm{x}} \mathrm{Al}\left(\mathrm{PO}_{4}\right)_{3}(0 \leq x \leq 0.4, \mathrm{LTAP})$ 에 대한 많은 연구가 진행되고 있다. ${ }^{24)} \mathrm{NASICON}$ 구조에서 이온 전도의 원리는 다음과 같다. Fig. 5 에 나타낸 바와 같이 $\mathrm{NASICON}$ 은 구조적으로는 $\mathrm{AO}_{6}$ 팔면체와 $\mathrm{PO}_{4}$ 의 사 면체가 모서리의 6 개의 산소원자를 공유하여 3차원적인 골격을 형성하고 있는데, 이 결정격자 사이에 3차원 채널 $\left(\mathrm{M}_{1}, \mathrm{M}_{1 / 2}, \mathrm{M}_{2}\right)$ 이 형성되고 여기에 양이온이 배치 되면서 이온전도가 가능해진다. 또한 앞서 진행된 연구에서 Aono는, $\mathrm{Zr}^{4+}$ 이온을 크기가 작은 $\mathrm{Ti}^{4+}$ 으로 치환하면 $\mathrm{NASICON}$ 의 골격구조는 유지하면서 이온이동에 더 적합 한 크기를 갖는 채널이 형성되어 이온전도도가 향상된다 고 보고한 바 있다. ${ }^{25)}$ 또한 LTAP 구조에서 $\mathrm{Ti}^{4+}$ 와 $\mathrm{P}^{5+}$ 이온을 3 가 양이온 $(\mathrm{Al}, \mathrm{Ga}, \mathrm{Sc}, \mathrm{In}, \mathrm{Y})$ 으로 치환한 경우에도 향상된 이온 전도성을 보였다. ${ }^{25)}$ 


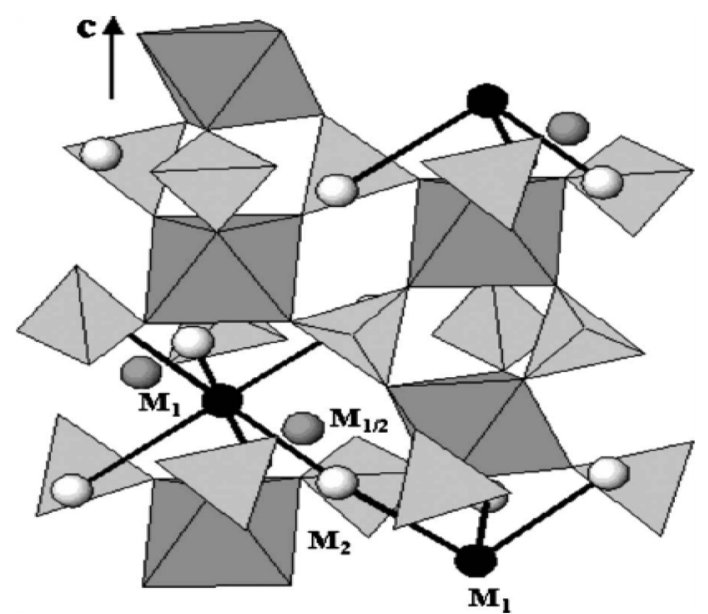

Fig. 5. A NASICON structure and $M_{1}, M_{1 / 2}$ and $M_{2}$ of the conduction network.

LTAP에서 리튬이 삽입되는 양이 $x$ 값에 의해 달라 지게 된다. $\mathrm{LTAP}$ 의 $x$ 값이 0.3 인 경우 $\mathrm{Li}_{1+\mathrm{x}} \mathrm{Ti}_{2-\mathrm{x}} \mathrm{Al}\left(\mathrm{PO}_{4}\right)_{3}$ 의 이온전도도가 가장 높은 값 $\left(10^{-2}-10^{-3} \mathrm{~S} / \mathrm{cm}\right)$ 을 나타내 었고 0.3 이하인 경우 입자 표면의 grain boundary에 전 도성이 없는 상이 형성되기 때문에 전체적으로 이온 전도도가 감소하게 된다. ${ }^{26)}$

\subsubsection{Thio-LISICON-type $\mathrm{Li}$ ion conductors}

Thio-LISICON (Lithium SuperIonic conductor)은 $\mathrm{Li}_{4 \mathrm{x}} M_{1-\mathrm{y}} M_{\mathrm{y}^{\prime}}^{\prime} \mathrm{S}_{4}\left(M=\mathrm{Si}, \mathrm{Ge}\right.$ and $\left.M^{\prime}=\mathrm{P}, \mathrm{Al}, \mathrm{Zn}, \mathrm{Ga}\right)$ 를 기본식으로 저마늄과 실리콘황화물로 이루어진 화합물 이다. ${ }^{27-29)} \mathrm{LISICON}$ 형태의 고체전해질에 대한 이온전도 기본 메커니즘은 $M, M^{\prime}$ 의 양이온들이 각각 치환되면서 이온전도성을 향상 시키게 되는데 Fig. 6에 나타낸 바와 같이 리튬이온은 $\mathrm{LiS}_{4}$ 사면체와 $\mathrm{LiS}_{6}$ 팔면체 안의 갈라진 틈에 배치되면서 $\left(\mathrm{LiS}_{6}\right)_{0}$ 의 팔면체 구조를 따라서 생성되 는 conduction pathway를 통해 이온이 이동하게 된다. ${ }^{30)}$

LISICON형태의 고체전해질에 대한 물질군 ${ }^{30}$ 은 Table 1 에 정리하였고, 기본화합물은 $\mathrm{Li}_{4} \mathrm{Ge}_{5} \mathrm{~S}_{4}, \mathrm{Li}_{3} \mathrm{PS}_{4}, \mathrm{Li}_{5} \mathrm{AlS}_{4}$, $\mathrm{Li}_{5} \mathrm{GaS}_{4}$ 등이 있다. 대표적인 물질인 $\mathrm{Li}_{4 x} \mathrm{Ge}_{1-\mathrm{x}} \mathrm{P}_{\mathrm{x}} \mathrm{S}_{4}$ 는 $\mathrm{Li}_{2} \mathrm{~S}, \mathrm{Ge}_{2} \mathrm{~S}, \mathrm{P}_{2} \mathrm{~S}_{5}$ 를 석영 글래스에 진공봉입하여 $600^{\circ} \mathrm{C}$ 에서 가열하면 얻어진다. $\mathrm{Li}_{4-\mathrm{x}} \mathrm{Ge}_{1-\mathrm{x}} \mathrm{P}_{\mathrm{x}} \mathrm{S}_{4}$ 는 3 개의 영역 $\mathrm{I}$ $(0 \leq x \leq 0.6)$, II $(0.6 \leq x \leq 0.8)$, 그리고 III $(0.8 \leq x \leq 1.0)$ 으로 구분되며, $x$ 값이 증가함에 따라 이온전도도가 증가하 고, $x$ 가 0.75 인 경우 최대의 이온 전도도 $\left(2.2 \times 10^{-3} \mathrm{~S} / \mathrm{cm}\right)$ 를 보여준다. ${ }^{31)}$ 그러나, thio-LISICON은 리튬 실리콘 황화물이기 때문에 공기 중에서 불안정한 단점이 있어 실제 리튬전지에 적용시키기 위해서는 이를 극복할 수 있는 추가적인 연구가 필요하다. ${ }^{32)}$
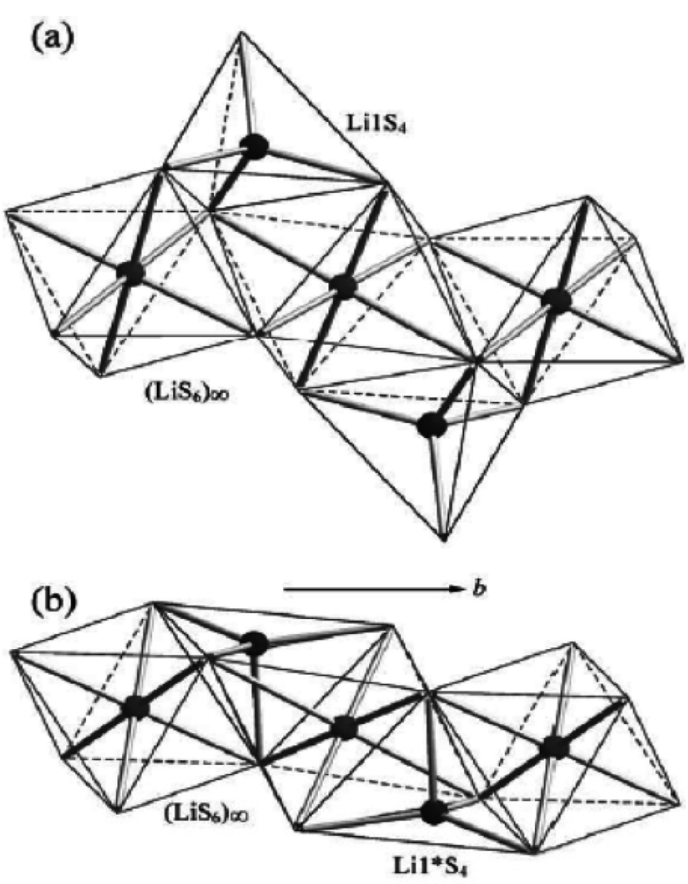

Fig. 6. Li-ion conduction pathway.

\subsubsection{Garnet-type $\mathrm{Li}$ ion conductors}

석류석 구조의 산화물인 garnet 구조는 $\mathrm{Li}_{5} \mathrm{La}_{3} \mathrm{M}_{2} \mathrm{O}_{12}$ $(\mathrm{M}=\mathrm{Ta}, \mathrm{Nb})$ 이다. Fig. 7에서 이온전도의 원리를 살 펴보면 $\mathrm{Li}(\mathrm{I}) \mathrm{O}_{6}$ 의 하나가 강하게 일그러지게 되면서 보통의 garnet 구조를 가지고 있는 구조에 공간이 생기게 되고 이로 인하여 생긴 리튬이온 vacancy로 리튬이온 전도도가 생기게 된다. ${ }^{33)} \mathrm{La}$ 을 $\mathrm{Ba}^{2+}, \mathrm{Sr}^{2+}, \mathrm{K}^{+}$등으로 치환했을 때 $4 \times 10^{-5} \mathrm{~S} / \mathrm{cm}$ 의 이온전도도를 나타낸다고 보고되고 있고, $\mathrm{Ta}$ 복합물인 $\mathrm{Li}_{5} \mathrm{La}_{3} \mathrm{Ta}_{2} \mathrm{O}_{12}$ 는 화학적으로 안정하여 리튬음극과 반응하지 않기 때문에 고체전해 질로서의 가능성이 많다고 보고되고 있다. ${ }^{34)}$

\subsubsection{Perovskite-type $\mathrm{Li}$ ion conductors}

$\mathrm{ABO}_{3}$ 구조를 가지고 있는 perovskite 물질들은 일반 적으로 높은 이온전도성을 가지고 있다고 보고되고 있으 며, 특히 $\mathrm{Li}_{0.34} \mathrm{La}_{0.51} \mathrm{TiO}_{2.94}$ (LLTO)의 경우 $2 \times 10^{-5} \mathrm{~S} / \mathrm{cm}$ 의 이온전도도를 가지고 있다. ${ }^{35)}$ 이들 perovskite구조를 가 지는 물질의 이온전도 메커니즘을 살펴보면, 층을 이루고 있는 각 $\mathrm{La}^{3+}$ layer와 그 사이에 존재하는 octahedral $\mathrm{TiO}_{6}$ 의 정전기적 인력에 의해 리튬이온의 전도가 진행된 다. ${ }^{36)}$ 즉, Fig. 8에서 보인 바와 같이 $\mathrm{La}_{2 / 3} \mathrm{TiO}_{3}$ 구조의 각 $\mathrm{A} 1, \mathrm{~A} 2$ site에서의 불규칙한 $\mathrm{La}^{+}$이온의 배치로 인하 여 사방정계구조의 약한 틀어짐현상이 발생하고, 이러한 격자 결함으로 리튬이온이 이동할 수 있는 경로가 형성 
Table 1. Properties of various thio-LISICON

\begin{tabular}{|c|c|c|}
\hline Compound & Material & Ion conductivity \\
\hline \multirow[t]{5}{*}{$\mathrm{Li}_{2} \mathrm{~S}-\mathrm{P}_{2} \mathrm{~S}_{5}$} & $80 \mathrm{Lis}_{2}-20 \mathrm{P}_{2} \mathrm{~S}_{5}$ & $3.2 \times 10^{-3} \mathrm{~S} \cdot \mathrm{cm}^{-1}$ \\
\hline & $70 \mathrm{Li}_{2} \mathrm{~S}-20 \mathrm{P}_{2} \mathrm{~S}_{6}$ & $2.1 \times 10^{-3} \mathrm{~S} \cdot \mathrm{cm}^{-1}$ \\
\hline & $\mathrm{Li}_{2} \mathrm{~S}-\mathrm{P}_{2} \mathrm{~S}_{5}-\mathrm{LiI}$ & $10^{-3} \mathrm{~S} \cdot \mathrm{cm}^{-1}$ \\
\hline & $\mathrm{Li}_{2} \mathrm{~S}-\mathrm{P}_{2} \mathrm{~S}_{5}$ 글래스세라믹 & $32 \times 10^{-3} \mathrm{~S} \cdot \mathrm{cm}^{-1}$ \\
\hline & LiI-Li 2 S- $\mathrm{P}_{2} \mathrm{~S}_{5}-\mathrm{P}_{2} \mathrm{O}_{5}$ & $1 \times 10^{-7} \mathrm{~S} \cdot \mathrm{cm}^{-1}$ \\
\hline \multirow[t]{7}{*}{$\mathrm{Li}_{2} \mathrm{~S}-\mathrm{SiS} \mathrm{S}_{2}$} & $\mathrm{Li}_{2} \mathrm{~S}-\mathrm{SiS}_{2}$ & $2 \times 10^{-3} \mathrm{~S} \cdot \mathrm{cm}^{-1}$ \\
\hline & $0.6 \mathrm{Li}_{2} \mathrm{~S}-0.4 \mathrm{SiS}_{2}$ & $\begin{array}{l}8 \times 10^{-3} \mathrm{~S} \cdot \mathrm{cm}^{-1} \\
(30 \% \text { LiI doped })\end{array}$ \\
\hline & $\mathrm{Li}_{2} \mathrm{~S}-\mathrm{SiS}_{2}-\mathrm{Li}_{3} \mathrm{PO}_{4}$ & $7.6 \times 10^{-4} \mathrm{~S} \cdot \mathrm{cm}^{-1}$ \\
\hline & $0.97\left[0.6 \mathrm{Li}_{2} \mathrm{~S}-0.4 \mathrm{SiS}_{2}\right]-0.03 \mathrm{Li}_{4} \mathrm{SiO}_{4}$ & $1.5 \times 10^{-3} \mathrm{~S} \cdot \mathrm{cm}^{-1}$ \\
\hline & $\mathrm{Li}_{2} \mathrm{~S}_{-} \mathrm{SiS}_{2}-\mathrm{LiSiO}_{4}$ & $1.1 \times 10^{-4} \mathrm{~S} \cdot \mathrm{cm}^{-1}$ \\
\hline & $\mathrm{Li}_{2}-\mathrm{SiS}_{2}-\mathrm{Li}_{\mathrm{x}} \mathrm{Mo}_{\mathrm{y}}$ & $\begin{array}{c}1.1 \times 10^{-3} \mathrm{~S} \cdot \mathrm{cm}^{-1}(\mathrm{M}=\mathrm{Si}, \mathrm{p}) \\
7 \times 10^{-3} \mathrm{~S} \cdot \mathrm{cm}^{-1}(\mathrm{M}=\mathrm{Ge})\end{array}$ \\
\hline & $\mathrm{Li} 3.4 \mathrm{Si} 0.4 \mathrm{P} 0.6 \mathrm{~S} 4$ & $6.4 \times 10^{-4} \mathrm{~S} \cdot \mathrm{cm}^{-1}$ \\
\hline \multirow[t]{3}{*}{$\mathrm{Li}_{2} \mathrm{~S}-\mathrm{SiS}_{2}-\mathrm{P}_{2} \mathrm{~S}_{5}$} & $0.6 \mathrm{Li}_{2} \mathrm{~S}-0.4\left[(1-\mathrm{x}) \mathrm{SiS}_{2-\mathrm{x}} \mathrm{P}_{2} \mathrm{~S}_{5}\right]$ & $0.7 \times 10^{-3} \mathrm{~S} \cdot \mathrm{cm}^{-1}$ \\
\hline & $\mathrm{Li}_{2} \mathrm{~S}_{-} \mathrm{SiS}_{2} \mathrm{P}_{2} \mathrm{~S}_{5}-\mathrm{LiI}$ & $2.1 \times 10^{-3} \mathrm{~S} \cdot \mathrm{cm}^{-1}$ \\
\hline & $50\left(0.67 \mathrm{Li}_{2} \mathrm{~S} \cdot 0.33 \mathrm{SiS}_{2}\right) \cdot 50\left(0.75 \mathrm{Li}_{2} \mathrm{~S} \cdot 0.25 \mathrm{P}_{2} \mathrm{~S}_{5}\right)$ & $1.2 \times 10^{-3} \mathrm{~S} \cdot \mathrm{cm}^{-1}$ \\
\hline \multirow[t]{8}{*}{$\mathrm{Li}_{2} \mathrm{~S}-\mathrm{GeS}_{2}$} & $\mathrm{Li}_{2}-\mathrm{GeS}_{2}$-LiI & $10^{-5} \mathrm{~S} \cdot \mathrm{cm}^{-1}$ \\
\hline & $\mathrm{Li}_{4} \mathrm{GeS}_{4}$ & $10^{-3} \mathrm{~S} \cdot \mathrm{cm}^{-1}$ \\
\hline & $\mathrm{Li}_{3.35} \mathrm{Ge}_{0.35} \mathrm{P}_{0.65} \mathrm{~S}_{4}$ & $2.39 \times 10^{-3} \mathrm{~S} \cdot \mathrm{cm}^{-1}$ \\
\hline & $95 \mathrm{Li}_{3} \mathrm{PS}_{4} \cdot 5 \mathrm{Li}_{4} \mathrm{GeS}_{4}$ & $9.9 \times 10^{-3} \mathrm{~S} \cdot \mathrm{cm}^{-1}$ \\
\hline & $\mathrm{Li}_{4-\mathrm{x}} \mathrm{Ge}_{1-\mathrm{x}} \mathrm{P}_{\mathrm{x}} \mathrm{S}_{4}$ & $10^{-3} \mathrm{~S} \cdot \mathrm{cm}^{-1}$ \\
\hline & $\mathrm{Li}_{3} \mathrm{PS}_{4}$ & $1.5 \times 10^{-4} \mathrm{~S} \cdot \mathrm{cm}^{-1}$ \\
\hline & $\mathrm{Li}_{4} \mathrm{SiPS}_{4}$ & $6.4 \times 10^{-4} \mathrm{~S} \cdot \mathrm{cm}^{-1}$ \\
\hline & $\mathrm{Li}_{4} \mathrm{GePS}_{4}$ & $2.2 \times 10^{-3}$ \\
\hline
\end{tabular}
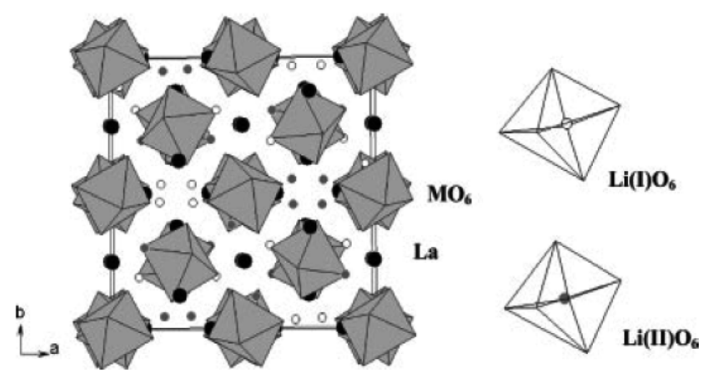

Fig. 7. Crystal structure of the garnet-type material $\left(\mathrm{Li}_{5} \mathrm{La}_{3} \mathrm{M}_{2} \mathrm{O}_{12}, \mathrm{M}=\mathrm{Nb}\right.$, Ta).

되는 것이다. 특이한 점은 LLTO에서 이온전도성을 측 정해 보면 bulk에서는 $1 \times 10^{-3} \mathrm{~S} / \mathrm{cm}$ 이지만 시료전체에서 는 $2 \times 10^{-5} \mathrm{~S} / \mathrm{cm}$ 로 매우 다르게 나타난다. 이러한 현상은 bulk보다 시료전체의 perovskite 구조에서 리튬이온이 자유롭게 이동하고 채워지는데 제한이 되기 때문이며,
LLTO의 결정립의 크기와 grain boundary의 이온전도 성이 서로 관련이 있다고 보고되고 있다. ${ }^{35)}$ 즉, 이런 입 계간의 접촉 저항이 리튬이온 전도도를 저하시키고 있는 것이다. LLTO 구조에서 $\mathrm{La}^{3+}$ 를 $\mathrm{Pr}, \mathrm{Nb}, \mathrm{Sm}$ 등으로 치환했을 경우 활성화 에너지의 증가로 인해 이온전 도도가 감소하게 된다. ${ }^{37)}$ 또한, $\mathrm{La}$ 을 부분적으로 $\mathrm{Na}, \mathrm{K}$ 등으로 치환했을 경우는 이온전도도가 향상되지 않는데, 이는 $\mathrm{Na}$ 이 리튬이온의 운동성을 감소시키고, $\mathrm{K}$ 은 격자 구조를 확장시키지만 이로 인한 격자구조 내부의 부분적 인 변형을 가져오게 되어서 이온전도도는 감소된다. ${ }^{34)}$

\subsubsection{LiPON-type Li ion conductors}

LiPON (Lithium phosphorus oxinitride)은 $\gamma-\mathrm{Li}_{3} \mathrm{PO}_{4}$ 의 결정체이다. 일반적인 $\mathrm{LiPON}$ 화합물인 $\mathrm{Li}_{2.8} \mathrm{PO}_{3.3} \mathrm{~N}_{0.46}$ 의 이온전도성은 $3.3 \times 10^{-6} \mathrm{~S} / \mathrm{cm}$ 을 나타내고, 활성화 에너지 는 $0.54 \mathrm{eV}$ 이다. $\mathrm{LiPON}$ 은 우수한 전극/전해질 계면 특성 을 갖는 재료로 박막화가 가능하여, 박막전지에 사용되고 


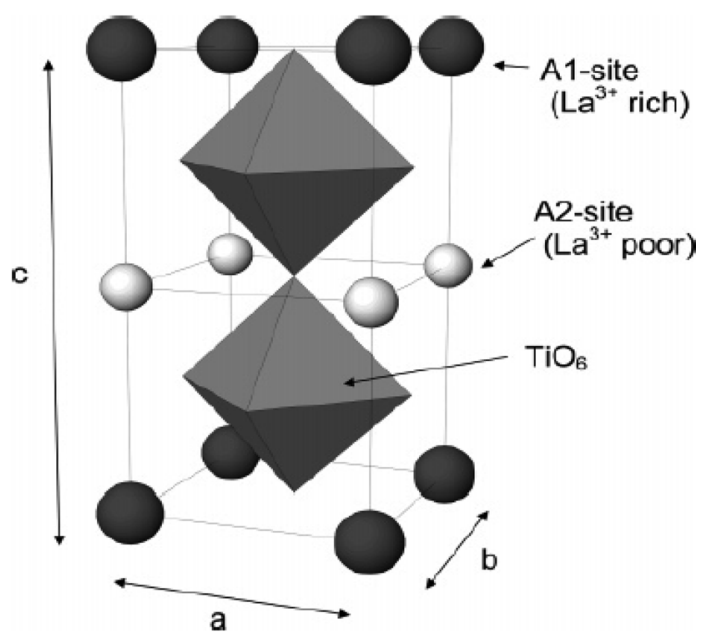

Fig. 8. Crystal structure of $\mathrm{La}_{2 / 3} \mathrm{TiO}_{3}$.

있는 대표적인 재료이다. ${ }^{38-43)}$ 박막전지의 제작은 질소 분위기의 스퍼터로 증착하는데, 질소 분압에 의해 이온 전도성과 활성화 에너지가 변화하게 된다. ${ }^{44)}$ 질소 분위 기에서 증착하는 이유는 Fig. 9에서 보인 바와 같이 질 소의 도입으로 cross-linking이 증가되면서 이온 전도에 대한 활성화 에너지가 감소하여 리튬이온의 운동성이 활발해지고 궁극적으로 이온전도도의 향상을 가져오 게 된다.

이상으로 현재 연구가 진행 중인 대표적인 무기물 고체전해질에 대하여 알아보았다. 황화물 계열의 고체 전해질은 $10^{-3}-10^{-5} \mathrm{~S} / \mathrm{cm}$ 의 높은 이온전도도를 보이지만, 대기 중에서 수분과 반응이 문제가 되고 있다. 산화물계 고체전해질은 상대적으로 낮은 이온전도성 $\left(10^{-6} \mathrm{~S} / \mathrm{cm}\right)$ 을 보이지만 대기 중에서 안정하여 제작 공정이 용이한 장점이 있다. 하지만 이온전도성을 높이기 위하여 결정 화시키게 되면 결정화 과정에서 형성되는 grain boundary 와 전극 물질의 계면에서 저항이 증가하는 단점이 있다. 또한 비정질인 $\mathrm{LiPON}$ 계열의 고체전해질은 조성에 따라 전도성이 변화할 수 있고 우수한 전극/전해질 계면 특성을 가지고 있지만 증착공정을 사용해야 하기 때문에

\section{LiPON}<smiles>O=P1([O-])CCP(=O)(OP(=O)([O-])[O-])CCP([O-])(OP(=O)([O-])OP(=O)([O-])[O-])=N1</smiles>

Fig. 9. Cross-linking structure of LiPON.
응용범위가 박막전지로 제한된다. 따라서, 이런 단점을 보완한 비정질 (글래스) 산화물 계열의 시스템을 구현 하여야 하는 방향으로 많은 연구가 이루어지고 있다.

\section{3. 고체 전해질 관련 연구 동향 및 업체동향}

\section{1. 고체전해질 논문 발표 및 특허 동향}

고체전해질 관련 연구 동향을 살펴보면 1997년 이후 논문 173편의 논문이 발표되었고, Fig. 10 에서 보듯이 고체전해질 연구 활동이 꾸준한 증가 추세를 보이는 것을 확인 할 수 있다. 고체전해질과 관련하여 다양한 물 질과 시스템이 연구되고 있는데, 물질 구조의 경우 글 래스, perovskite 관련 물질의 연구가 매우 활발히 진 행되고 있으며, 물질 시스템은 산화물(oxide)과 황화물 (sulfide) 계열의 연구가 활발하다. 국가별 비율로는 일본 이 $65.5 \%$ 로 압도적이며, 한국 $9.9 \%$, 프랑스 $6.3 \%$, 중국 $4.0 \%$ 순이다. 또한 고체전해질 관련 연구는 대부분 $(95 \%)$ 학계에서 수행 되었는데 이는 현재까지 상용화까지 해 결해야 할 문제가 많기 때문인 것으로 판단된다. 발표된 논문은 오사카부립대가 가장 많으며, 동경공대, 가큐슈잉 대학 순으로 일본의 학계에서 현재까지 많은 연구가 진 행되었음을 알 수 있다.

이온전도성 변화 추이를 산화물계와 비산화물계 고 체전해질에 대해 발표년도와 이온전도도 변화로 살펴 보았다. Fig. 11에 보인 바와 같이 산화물계 비산화물계 고체전해질의 연구는 2000 년 이후 활발해지고 있다. 먼저 산화물계 고체전해질은 초기 이온전도도가 $10^{-13} \mathrm{~S} / \mathrm{cm}$ 수준에서 최근에는 $10^{-3} \mathrm{~S} / \mathrm{cm}$ 까지 발전하였고, La-Li-Ti$\mathrm{O}-\mathrm{F}$ 시스템의 경우 현재 $2.3 \times 10^{-3} \mathrm{~S} / \mathrm{cm}$ 의 높은 이온전 도도를 보여주고 있다. 황화물계 고체전해질도 $10^{-3} \mathrm{~S} / \mathrm{cm}$ 까지 이온전도도가 높아졌는데, 특히 $\mathrm{Li}_{2} \mathrm{~S}-\mathrm{P}_{2} \mathrm{~S}_{5}$ 및 $\mathrm{Li}_{2} \mathrm{~S}-$ $\mathrm{SiS}$ 시스템의 경우 이온전도도 특성이 매우 우수함을 알 수 있다. 또한 황화물계 고체전해질은 이데미츠흥산에서 개발한 고체전해질의 이온전도도다 $4 \times 10^{-3} \mathrm{~S} / \mathrm{cm}$ 로 세계 최고 수준의 결과를 보여주는데 개발된 고체전해질은 $\mathrm{Li}_{2} \mathrm{~S}-\mathrm{P}_{2} \mathrm{~S}_{5}$ 계열의 물질로 추정 된다.

2003년 이후 출원 건 수를 비교해보면 Idemitus, Panasonic, Ohara, Toyota순으로 Idemitus가 2003년 이후 지속적인 연구 개발을 하고 있다는 것을 보여준다. 하지 만 Panasonic, Toyota도 2006년 이후 특허 건수가 다시 증가하는 것을 보여주는 것으로 보아 고체전해질 연구에 많은 관심을 가진 것으로 생각된다. Table 2에 보인 바와 같이 연도별 특허 및 발명자의 수를 살펴보면, 초기에 Panasonic, Sanyo 등에서 많은 인원으로 연구를 진행 하였지만 연구인력이 점점 감소하고 있는 것으로 판단되 는 반면, Idemitus, Ohara, Toyota 등 업체에서는 전고체 전지관련 연구인력은 증가하는 것으로 추정된다. 

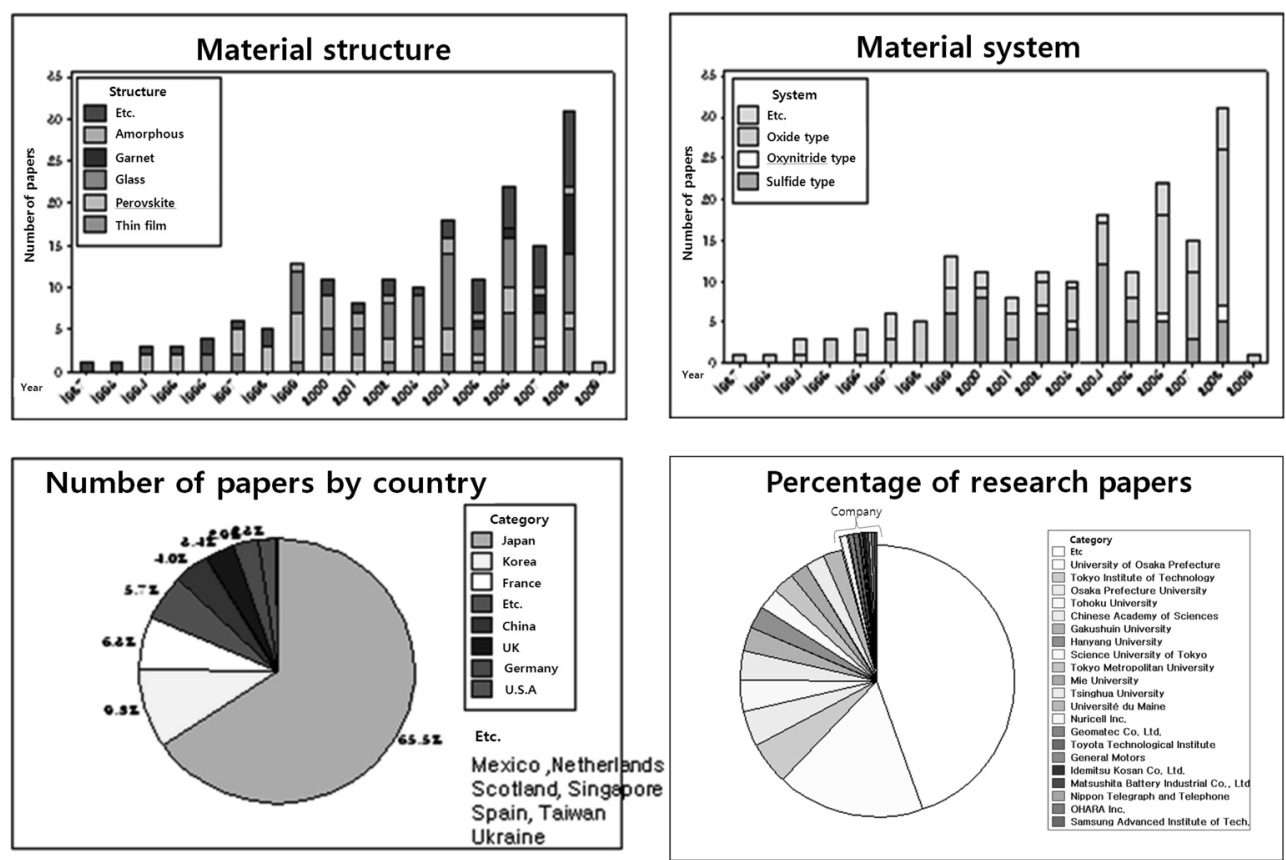

Fig. 10. Research Trend for solid state electrolyte.

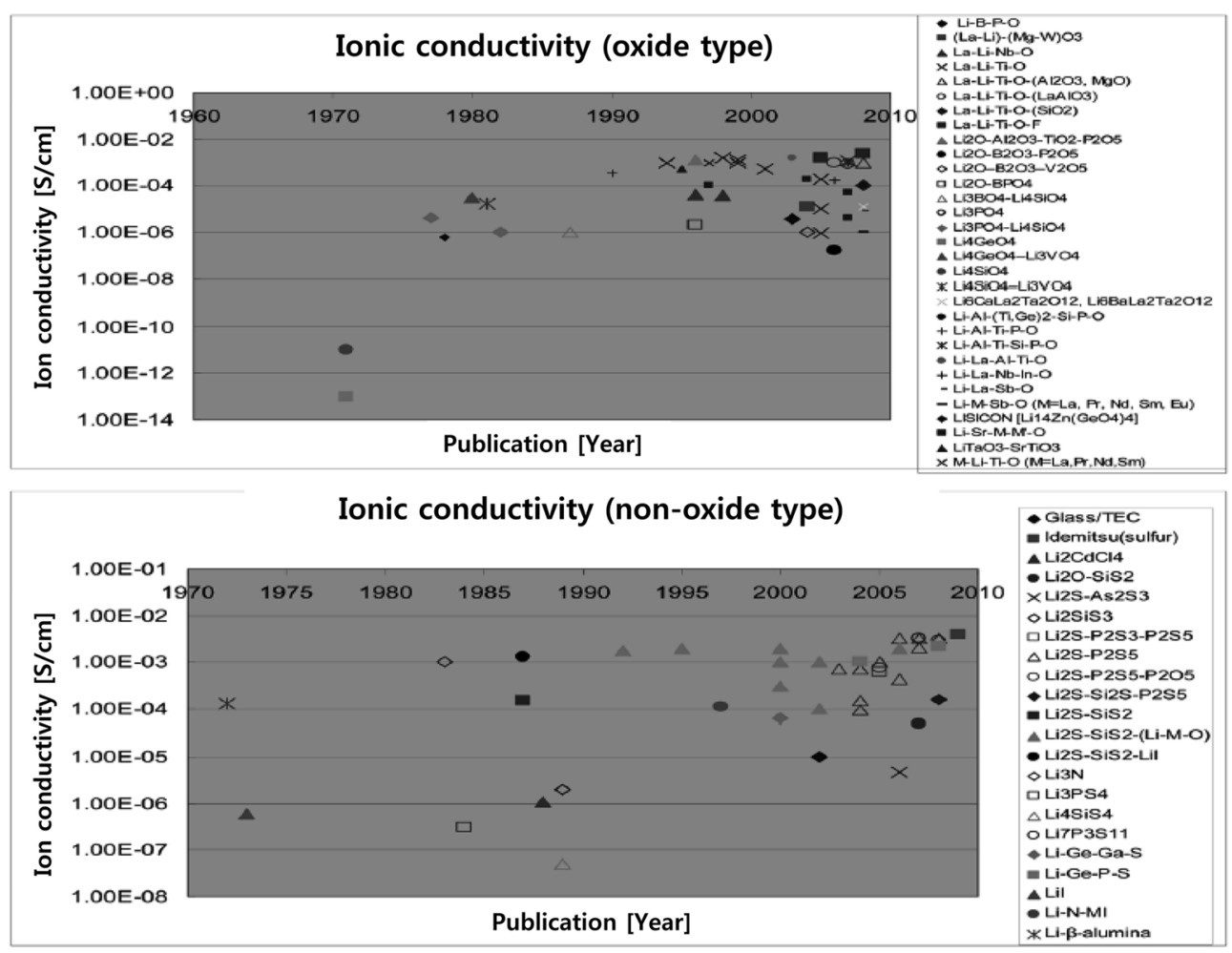

Fig. 11. Developments of ion conductivities of solid electrolyte materials. 


\section{2. 업체 동향}

\subsection{1. 도요타 자동차}

도요타 자동차는 2008년 6월에 혁신적인 전지를 개 발할 목적으로 기초연구부문에 '전지연구부'를 신설하여 포스트 리튬 전지에 관한 연구를 수행 중이다. 도요타 자동차는 포스트 리틈 이온 2차전지 후보 중에서 특히 전고체전지에 큰 관심을 보이고 있으며, 최근 에어로졸 디포지션법 (Aerosol Deposition Method)에 의해 고체 전해질 재료를 박막으로 적층하여 금속 기판 위에 3 층 구조로 이루어진 고체전해질 박막 리튬이온전지를 시험 제작하고 배터리로서의 특성을 확인하였다. Fig. 12은 에 어로졸 디포지션법에 의해 제조된 박막 시스템의 SEM사 진을 보여주고 있으며, 현재 이온전도성을 $3.5 \times 10^{-5} \mathrm{~S} / \mathrm{cm}$ 까지 향상시켰다. 에어로졸 디포지션법에서는 입자가 기판에 충돌할 때 $3 \mathrm{GPa}$ 이상의 높은 압력이 걸리기 때 문에 매우 치밀한 박막 구조를 형성 할 수 있고, 기판 재료나 적층하는 박막 표면의 한정된 부분에만 고압이 걸리기 때문에 열에 의한 상호 확산도 발견되지 않았다. 에어로졸 디포지션법에 의해 제작된 고체전해질 리튬 전지의 성능은 아직 실용화 수준에는 미치지 못하지만, 상온에서 사용 가능한 에어로졸 디포지션법은 박막 전지 를 생산하는 유용한 제작 방법이며 그 응용 가능성 또한 많은 것으로 판단된다. ${ }^{45)}$

\subsection{2. 이데미츠 훙산}

이데미츠 흥산은 고체 재료만은 사용하여 리튬이온 전지를 제작하는데 성공하였다. 이는 고체재료와 양극의

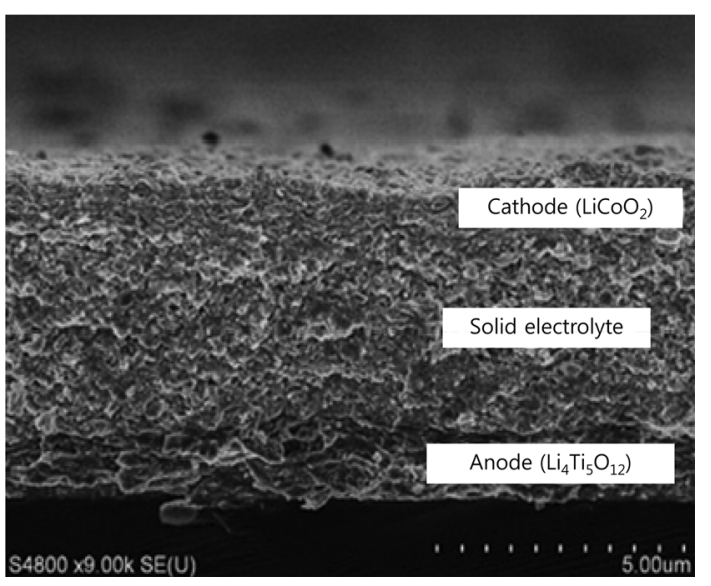

Fig. 12. A structure of the solid electrolyte between the cathode and anode prepared by aerosol deposition method.

접합부를 혼합함으로 통상적인 가연성 액체 재료 (전 해질 등) 가 불필요하게 되었음을 의미하며, 이렇게 제작 된 전고체전지는 기존의 리튬이온 2 차전지와 비슷한 출 력을 나타낸다. 따라서, 현재까지 전지의 안정성 관련 문제점인 발화나 전해액의 누액 현상 등의 문제점 해결 이 가능하며, 양산기술의 개발을 서둘러 단기간 내에 사 업화를 목표로 하고 있다. 이데미츠 흥산은 2009년 전고 체 리튬이온전지 개발하였으며, 현재까지 황화 리튬을 주 성분으로 하는 고체전해질 사용하여 이온전도도를 상당 히 향상시켰다. 최근 양극재료 $\left(\mathrm{LiCoO}_{2}\right)$ 와 고체전해질을 접합부에서 분자레벨로 균일하게 혼합/성형하여 두께

Table 2. Summary of published patents

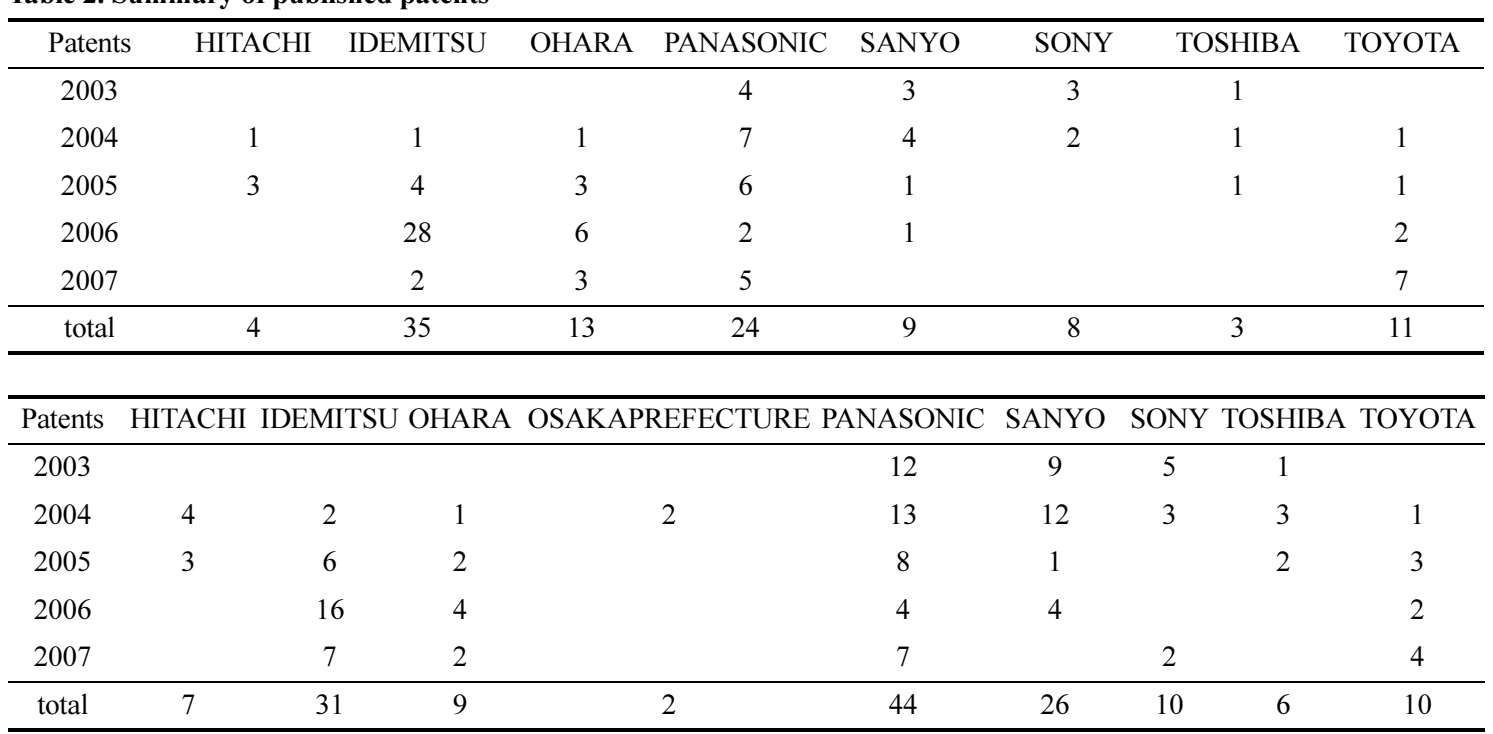


$1 \mathrm{~mm}$ 명함사이즈의 전지를 시제작하였으며, 이 전지는 $10 \mathrm{~mA} / \mathrm{cm}^{2}$ 의 출력을 갖는다고 보고되었다. 또한 이 고체 전해질은 약 $400^{\circ} \mathrm{C}$ 까지 열적으로 안정한 구간을 가지고 있다. 이는 고체 전해질을 사용한 형태로는 세계 최고수 준이고 $100^{\circ} \mathrm{C}$ 이상의 고온이나 대형 축전용의 고전압에 대해서도 응용 가능 하다. 또한 대용량화를 위해 음극뿐 아니라 양극재료의 개량연구도 진행 중이고 휴대전자 기기 이외에도 자동차용의 전원, 태양전지용 축전장치 등으로 분야를 확장하고 있다.

\subsection{3. 오하라}

유리질계 세라믹 복합체로서 $\mathrm{Li}_{2} \mathrm{O}-\mathrm{Al}_{2} \mathrm{O}_{3}-\mathrm{SiO}_{2}-\mathrm{P}_{2} \mathrm{O}_{5}$ $\mathrm{TiO}_{2}-\mathrm{GeO}_{2}$ 계를 사용하여 $\mathrm{Li}_{1+\mathrm{x}+\mathrm{y}} \mathrm{Al}_{\mathrm{x}}(\mathrm{Ti}, \mathrm{Ge})_{2-\mathrm{x}} \mathrm{Si}_{\mathrm{y}} \mathrm{P}_{3-\mathrm{y}} \mathrm{O}_{12}$ 의 main phase를 갖는 고체전해질 $(\mathrm{Li}$ 치환 NASICON형)을 합성하였다. 이 고체전해질의 이온 전도도는 $10^{-4} \mathrm{~S} / \mathrm{cm}$ (상온 기준)수준이며, 현재 외부의 요구에 따라 맞춤 제작 이 가능하다 (Fig. 13). 현재 오하라에서 제작된 NASICON sheet을 사용하여 $\mathrm{Li}-\mathrm{Air}, \mathrm{Li}-\mathrm{Cu}, \mathrm{Li}-\mathrm{Ni}$ 등 다양한 전 지에 대한 연구가 진행되고 있다. ${ }^{46)}$

\subsection{4. 삼성종합기술원 (SAIT)}

대면적 박막 전지용 전지개발을 주로 수행하였는데 최 근 요코마하 연구소에서 전고체전지에 대하여 기초연구 를 시작하였고, 황화물계 고체전해질에 대한 기초자료를 확보하였다. 고체전해질로 $\mathrm{Li}_{2} \mathrm{~S}-\mathrm{P}_{2} \mathrm{~S}_{5}$, 양극은 $\mathrm{LiCoO}_{2}$ (LCO) 또는 LiNiCoMn (NCM), 음극은 graphite를 사용 하여 Ar-filled glove box 안에서 조립(Fig. 14)하여 평가 를 하였다. Fig. 15에서 보인 바와 같이 양극재료 표면에 $\mathrm{Al}$ 처리를 실시했을 경우에 $\mathrm{Li}_{2} \mathrm{~S}-\mathrm{P}_{2} \mathrm{~S}_{5} \quad(80-20 \mathrm{~mol} \%)$ 고체전해질에서 300 회 충·방전 후 용량 유지율이 약 $85 \%$ 까지 높아졌다. $\mathrm{Al}$ 처리는 양극재료와 고체전해질의

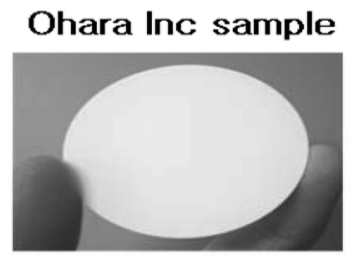

Ф2" Dia. $\times 250 u m t$

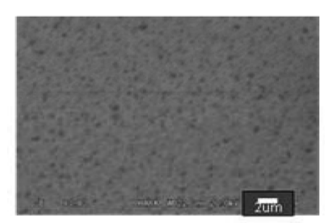

SEM photograph of surface

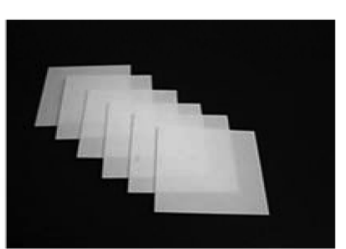

$\square 1$ "Sq. x 150umt

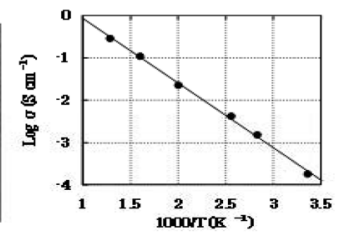

Fig. 13. Information for Ohara LISICON samples.
계면저항을 줄일 수 있고, 이때 이온전도도는 $10^{-4} \mathrm{~S} / \mathrm{cm}$, 방전용량은 $105 \mathrm{mAh} / \mathrm{g}$ 으로 요코하마 연구소의 코바야 시가 발표하였다. ${ }^{47)}$

\section{4. 결 론}

이상과 같이 고체전해질의 원리와 개발 동향에 대하여 살펴보았다. 최근 전지는 자동차용 전지, 고정용 전지에 서 축전용도로 사용할 대형전지로 큰 주목을 받고 있는데 그 배경에는 현재까지 주류를 이루었던 휴대기기용 소 형전지가 아닌, 전기자동차 고정용 축전지용도 등으로 사용할 대형전지의 수요가 급격하게 높아지고 있기 때문 이다. 이 때문에 이제까지와 다른 전지적 특성이 요구되 고 있고, 연구개발의 방향성 또한 크게 변화하고 있다. 특히 대형전지로 가게 되면서 안정성 확보와 전지 수명 의 증가 방면에서는 현재의 리튬이차 전지보다 더 향상된 성능이 요구되고 있다. 이를 달성하기 위해서는 안정적인 이온전도성를 가지는 고체전해질 개발이 반드시 선행되

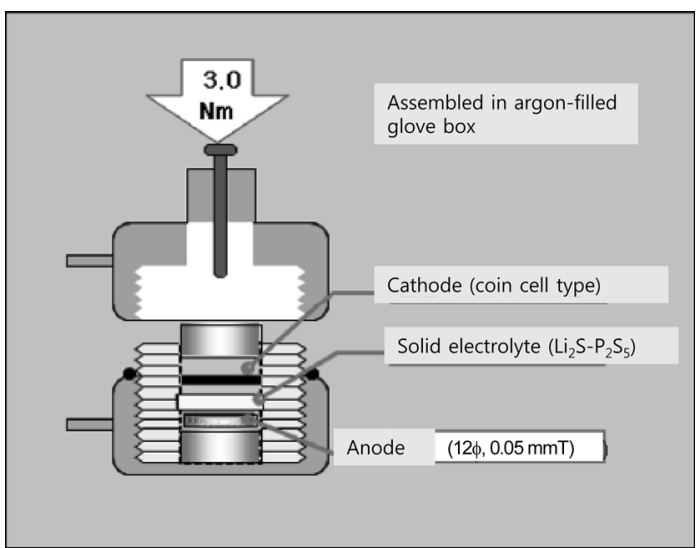

Fig. 14. Schematic diagram of all solid battery (SAIT).

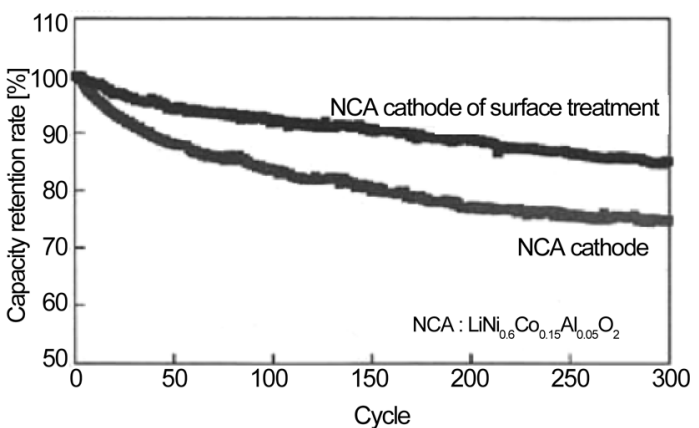

Fig. 15. The results of charge/discharge performance of all solid battery (SAIT). 
어야 한다. 현재까지는 황화물계와 산화물계 고체전해질 개발이 주를 이루고 있고 일부 연구결과는 액체전해질 수 준까지의 이온전도성을 가지는 것을 발표하기도 하였다.

그렇지만 현재 고체전해질은 아직까지는 액체전해질에 비해 상대적으로 낮은 이온전도도를 보이며, 계면 접촉저 항의 증가 및 물과 반응에 의한 황화수소 발생 (황화물인 경우) 등의 단점을 극복/보완하기 위해 많은 연구가 진행 되어야 한다. 향후 산업계나 학계에서 고체전해질에 대한 연구가 활발히 진행된다면, 다양한 용도의 리튬 이차전지 에 대한 안정성 높은 전지의 개발이 이루어 질 것으로 생각된다.

\section{감사의 글}

이 논문은 2011학년도 성신여자대학교 학술연구 조 성비 지원에 의하여 연구되었습니다.

\section{참고문헌}

1. W, Tahil, 'The Zinc Air Battery and the Zinc Economy: A Virtuous Circle' Meridian International Research, (2007).

2. G. Girishkumar, B. McCloskey, A.C. Luntz, S. Swanson, and W. Wilcke, 'Lithium-Air Battery: Promise and Challenges' J. Phys. Chem. Lett., 1, 2193 (2010).

3. X. Zhuo-bing, M. Ming-you, W. Xian-ming, H. Ze-qiang and C. Shang, 'Thin -film lithium-ion battery derived from $\mathrm{Li}_{1.3} \mathrm{Al}_{0.3} \mathrm{Ti}_{1.7}\left(\mathrm{PO}_{4}\right)_{3}$ sintered pellet' Trans. Nonferrous Met. Soc. China, 16, 281 (2006).

4. A. D. Pasquier, I. Plitz, S. Menocal, and G. Amatucci, 'A comparative study of Li-ion battery, supercapacitor and nonaqueous asymmetric hybrid devices for automotive applications' J. Power Sources, 115, 171 (2003).

5. K. Kurashima and T. Tamakoshi, 'Recent sodium sulfur battery applications in Japan' TOKYO ELECTRIC POWER COMPANY.

6. J. B. Bates, N. J. Dudney, B. Neudecker, A. Ueda, and C.D. Evans, 'Thin-film lithium and lithium-ion batteries' Solid State Ionics, 135, 33 (2000).

7. J. B. Bates, N. J. Dudney, D. C. Lubben, G. R. Gruzalski, B. S. Kwak, X. Yu and R. A. Zuhr, 'Thin-film rechargeable lithium batteries' J. Power Sources,54, 58 (1995).

8. R. A. Huggins, 'Lithium alloy negative electrodes' $J$. Power Sources, 81, 13 (1999).

9. J. O. Besenhard, J. Ynag, and M. Winter, 'Will advanced lithium-alloy anodes have a chance in lithium-ion batteries' J. Power Sources, 68, 87 (1997).

10. A. Karthikeyan, P vinatier, and A. Levasseur, 'Study of lithium glassy solid electrolyte/electrode interface by impedance analysis' Bull. Mater. Sci., 23, 179 (2000).

11. P. Knauth, 'Inorganic solid Li ion conductors: An overview' Solid State Ionics, 180, 911 (2009).

12. J. W. Fergus, 'Ceramic and polymeric solid electrolytes for lithium-ion batteries' J. Power Sources, 16, (2010).

13. J. H. Kennedy, S. Sahami, S. W. Shea, and Z. Zhang, 'Preparation and conductivity measurements of $\mathrm{SiS}_{2}-\mathrm{Li}_{2} \mathrm{~S}$ glasses doped with $\mathrm{LiBr}$ and LiCl' Solid State Ionics, 18, 368 (1986).

14. K. Takadaa, T. Inada, A. Kajiyama, H. Sasaki, S. Kondo, M. Watanabe, M. Murayama, and R. Kanno, 'Solid-state lithium battery with graphite anode' Solid State Ionics, 158, 269 (2003).

15. A, Overton, 'Inorganic Chemistry Fourth Edition' p 729 (2006).

16. K. H. Cho, 'Fabrication $\mathrm{Li}_{2} \mathrm{O}-\mathrm{B}_{2} \mathrm{O}_{3}-\mathrm{P}_{2} \mathrm{O}_{5}$ Solid Electrolyte by Aerosol Flame Deposition for ThinFilm Battery' Ph.D. Dissertation, Hanyang University, Seoul, Korea (2008).

17. M. L. F. Nascimento and N. O. Dantas, 'Anderson-Stuart model of ionic conductors in $\mathrm{Na}_{2} \mathrm{O}-\mathrm{SiO}_{2}$ glasses' Ciência \& Engenharia, 12, 7 (2003).

18. N. Kamaya, K. Homma, Y. Yamakawa, M. Hirayama1, R. Kanno, M .Yonemura, T. Kamiyama, Y. Kato, S. Hama, K. Kawamoto, and A. Mitsui, 'A lithium superionic conductor' Nat. Mater, 10, 682 (2011).

19. S. Stramare, V. Thangadurai, and W. Weppner, 'Lithium Lanthanum Titanates: A review' Chem. Mater, 15, 3974 (2003).

20. V. Thangadurai, H. Kaack, and W. J.F. Weppner, 'Novel fast lithium ion conduction in Garnet-type $\mathrm{Li}_{5} \mathrm{La}_{3} \mathrm{M}_{2} \mathrm{O}_{12}$ $(\mathrm{M}=\mathrm{Nb}, \mathrm{Ta})$, J. Am. Ceram. Soc., 86, 437 (2003).

21. K. Arbi, A. Kuhn, J. Sanz, and F. Garcia-Alvarado, 'Characterization of Lithium Insertion NASICON-Type $\mathrm{Li}_{1-\mathrm{x}} \mathrm{Ti}_{2-\mathrm{x}} \mathrm{Al}_{\mathrm{x}}\left(\mathrm{PO}_{4}\right)_{3}$ and Its Electrochemical Behavior' $J$. Electrochem. Soc., 157, 654 (2010).

22. R. Komiya, A. Hayashi, H. Morimoto, and M. Tatsumisago, 'Solid state lithium secondary batteries using an amorphous solid electrolyte in the system' Solid State Ionics, 140, 84 (2001).

23. G. X. Wang, D. H. Bradhurst, S. X. Dou, and H. K. Liu, ' $\mathrm{LiTi}_{2}\left(\mathrm{PO}_{4}\right)_{3}$ with NASICON-type structure as lithiumstorage materials' J. Power Sources, 124, 231 (2003).

24. J. L. Narváez-Semanate and A.C.M. Rodrigues, 'Microstructure and ionic conductivity of $\mathrm{Li}_{1+\mathrm{x}} \mathrm{Al}_{\mathrm{x}} \mathrm{Ti}_{2-\mathrm{x}}\left(\mathrm{PO}_{4}\right)_{3}$ ', Solid State Ionics, 181, 1197 (2010).

25. H. Aono and E. Sugimoto, 'Electrical property and sinterability of $\mathrm{LiTi}_{2}\left(\mathrm{PO}_{4}\right)_{3}$ mixed with lithium salt $\left(\mathrm{Li}_{3} \mathrm{PO}_{4}\right.$ or $\mathrm{Li}_{3} \mathrm{BO}_{3}$ )' Solid State Ionics, 47, 257 (1991).

26. K. Arbi, S. Mandal, J. M. Rojo, and J. Sanz, 'Dependence of Ionic Conductivity on Composition of Fast Ionic Conductors $\mathrm{Li}_{1+\mathrm{x}} \mathrm{Ti}_{2-\mathrm{x}} \mathrm{Al}_{\mathrm{x}}\left(\mathrm{PO}_{4}\right)_{3}, 0 \leq \mathrm{x} \leq 0.7$. A Parallel NMR and Electric Impedance Study' Chem. Mater, 14, (2002).

27. R. Kanno and M. Murayama, J. Electrochem. Soc., 148, 742 (2001).

28. Z. Liu, Fuqiang Huang, J. Yang, Baofeng Wang, and J. Sun, 'New lithium ion conductor, thio-LISICON lithium zirconium sulfide system' Solid State Ionics, 179, (2008).

29. M. Murayama, N. Sonoyama, A. Yamada, and R. Kanno, 'Material design of new lithium ionic conductor, thio- 
LISICON in the $\mathrm{Li}_{2} \mathrm{~S}_{-} \mathrm{P}_{2} \mathrm{~S}_{5}$ system' Solid State Ionics, 170, 173 (2004).

30. M. Murayama, R. Kanno, Y. Kawamoto, and T. Kamiyama, 'Structure of the thio-LISICON, $\mathrm{Li}_{4} \mathrm{GeS}_{4}$ ' Solid State Ionics, 154, 789 (2002)

31. Y. Shibutani, F. Mizuno, A. Hayashi, and M. Tatsumisago, Chemistry for Sustainable Development, 15, 219 (2007).

32. H. Hyooma and K. Hayahi, Mater. Res. Bull., 23, 1399 (1988).

33. V. Thangadurai and W. Weppner, ${ }^{\prime} \mathrm{Li}_{6} \mathrm{ALa}_{2} \mathrm{Ta}_{2} \mathrm{O}_{12}(\mathrm{~A}=$ $\mathrm{Sr}, \mathrm{Ba}$ ): Novel Garnet-Like Oxides for Fast Lithium Ion Conduction' Adv, Funct. Mater, 15, 107 (2005).

34. S. Stramare, V. Thangadurai, and W. Weppner, 'Lithium Lanthanum Titanates: A Review' Chem. Mater, 15, 3974 (2003).

35. Y. Inaguma, C. Liquan, M. Itoh, and T. Nakamura, 'High Ionic Conductivity in Lithium Lanthanum Titanate' Solid State Commun., 86, 689 (1993).

36. M. Nakayama, T. Usui, Y. Uchimoto, M. Wakihara, and M. Yamanoto, Changes in Electronic Structure upon
Lithium Insertion into the A-Site Deficient Perovskite Type Oxides (Li,La)TiO ${ }_{3}^{\prime}$ J. Phys. Chem. B, 109, 4135 (2005).

37. K. Mizumoto and S. Hayashi, 'Lithium ion conduction in A-site deficient perovskites' Solid State Ionics, 116, 263. (1999).

38. US 특허 5314765.

39. US 특허 5338625 .

40. US 특허 5512147.

41. US 특허 5567210.

42. US 특허 5597660 .

43. US 특허 5612152.

44. N. J. Dudney and B. J. Neudecker, 'Solid state thin-film lithium battery systems' Curr. Opin. Solid St. M., 4, 479 (1999).

45. http://www.aist.go.jp/aist_j/press_release/pr2010/ pr20101105/pr20101105.html.

46. http://www.ohara-inc.co.jp/en/product/electronics/ licgc.html.

47. NIKKEI ELECTRONICS 2010.5.17. 